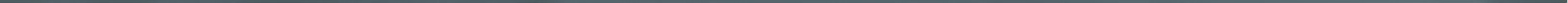


Kapittel 8

\section{ORGANISERING OG SAMARBEID MELLOM KOMMUNE OG NAV OM INTRODUKSJONSPROGRAMMET OG HURTIGSPORET}

«Jeg skulle ønske vi hadde et bedre samarbeid»

\section{SAMMENDRAG}

I dette kapittelet tar jeg for meg hvordan en kommune og et NAV-kontor i Nord-Norge er organisert, for å lykkes med introduksjonsprogrammet og hurtigsporet. 15 kvalitative intervjuer gjennomført høsten 2017 med ansatte i flyktningetjenesten og ansatte i NAV danner grunnlag for konklusjonen om at flyktningetjenesten i kommunen og NAV både er organisatorisk atskilt og sliter med å få til et fungerende samarbeid i introduksjonsprogrammet og hurtigsporet. Det manglende samarbeidet påvirker nyankomne flyktningers overgang fra introduksjonsprogram til arbeid og skaper derfor langvarige, negative konsekvenser for flyktningene. De kommer ikke nødvendigvis raskere i arbeid, og i noen tilfeller havner de på sosialhjelp. 


\section{INNLEDNING}

Dette kapittelet er et bidrag fra arbeidspakke 4 « $\AA$ inkludere flyktninger i ordinært arbeidsliv - en evaluering av samhandlingen mellom stat-kommune og av «hurtigspor» for flyktninger». Arbeidspakken er en del av forskningsprosjektet arbeidsinkludering, læring og innovasjon i NAV, som er en del av samarbeidet mellom UiT Norges arktiske universitet og NAV Troms og Finnmark. For nærmere beskrivelser av forskningsprosjektet som helhet og arbeidspakke 4 se kapittel 1 i denne antologien.

Arbeidsintegrering av innvandrere og nyankomne flyktninger har vært et høyaktuelt tema i det norske samfunnet de senere årene. For å gjøre nyankomne flyktninger mer økonomisk selvstendige samt øke sysselsettingsandelen har Norge innført obligatorisk introduksjonsprogram (Tronstad, 2015). Den store flyktningebølgen i 2015 og 2016 forsterket den politiske målsettingen om å få nyankomne flyktninger raskere ut i arbeid. Arbeidet med integrering og inkludering av nyankomne flyktninger går sakte, og mange kommer aldri i jobb (Bratsberg, Raaum \& Røed, 2016; Olsen, 2019). Våren 2016 kom derfor Arbeidslivs- og pensjonspolitisk råd med et forslag til et hurtigspor for nyankomne flyktninger, etter innspill fra hovedorganisasjonene i arbeidslivet. Et hurtigspor foregår innenfor introduksjonsprogrammets rammer, men skiller seg ut ved at det er et kortere og et mer tilpasset arbeidsrettet løp, som i hovedsak er tiltenkt nyankomne flyktninger med medbrakt kompetanse som er etterspurt i arbeidslivet. Hurtigsporet ble etablert gjennom en samarbeidsavtale mellom partene i arbeidslivet og regjeringen. Dette statlige tiltaket har NAV hovedansvaret for, og det forventes at hurtigsporet skal bidra til å fremme rask og direkte inkludering i arbeidslivet (Arbeids- og sosialdepartementet, NHO, LO, VIRKE, Unio, Spekter, Akademikerne, KS \& YS, 2016; Rambøll \& Halogen, 2019). Tronstad (2019) og Rambøll og Halogen (2019) fremhever at samarbeid mellom instanser som for eksempel kommuner som har ansvar for introduksjonsprogram, og NAV er essensielt for å få nyankomne flyktninger i arbeid. Tronstad (2015) skriver at i et slikt samarbeid ligger det flere muligheter, men også utfordringer som kan føre til ineffektiv organisering av tjenestene. For nærmere beskrivelser av NAVs samarbeidsplikt og samarbeid i arbeidsrettet bistand se kapittel 7 i denne antologien.

I henhold til NAV-loven (2006) er NAV et partnerskap mellom stat og kommune. Uavhengig om introduksjonsprogrammet er organisert i eller utenfor NAV, vil nyankomne flyktninger derfor være berørt av kommunal organisering. Jeg skal i dette kapittelet se nærmere på hvordan en kommune 
organiserer arbeidet med introduksjonsprogrammet og hurtigsporet. Dette innebærer at jeg ser på hvordan kommunen og NAV-kontoret er organisert, og hvordan de samarbeider for å lykkes med å få nyankomne flyktninger i arbeid.

\section{METODE}

Datainnsamlingen tilknyttet dette kapittelet pågikk høsten 2017 til sent 2018. Studien var meldt inn til Norsk senter for forskningsdata (meldeskjema 54599). Kapittelet bygger på intervjuer med kommunalsjef, ansatte i NAV og i flyktningetjenesten i Fjord kommune, totalt 15 intervjuer med henholdsvis ledere, nestledere og ansatte. Av hensyn til anonymitet er navnet på den aktuelle kommunen blitt endret til «Fjord» kommune. I Fjord kommune er flyktningetjenesten og NAV organisert i ulike enheter. NAV lokalt arbeider helhetlig med brukerne, og på bakgrunn av dette vil det ikke bli skilt mellom NAV stat og NAV kommune i dette kapittelet.

Forskerteamet hadde kontaktpersoner i NAV. Vi tok kontakt med disse i rekrutteringsfasen av informanter for å få navn på andre personer i NAV og flyktningetjenesten som kunne være relevante for oss å intervjue. Forskerteamet ble deretter splittet i team på to personer som gjennomførte intervjuene sammen. Dette har sammenheng med at vi ville sikre robusthet på tvers av områdene i arbeidspakken. For forskerteamet var det viktig å få fyldige og relevante deskriptive data i intervjuene. Ifølge Kvale og Brinkmann (2017, s. 47) innebærer dette at man som intervjuer oppfordrer informantene til å beskrive handlinger, opplevelser og følelser. På den måten søker man etter de nyanserte beskrivelsene. På bakgrunn av dette oppmuntret vi informantene til å reflektere fritt rundt sine opplevelser og erfaringer. Vi brukte delvis strukturerte intervjuguider som var felles for hele arbeidspakken. Ifølge Kvale og Brinkmann (2017, s. 156) er dette en måte å innhente beskrivelser fra informantenes livsverden på, der det brukes både fastsatte og åpne spørsmål for å få frem fruktbare beskrivelser og opplevelser. Alle informantene har gitt et informert samtykke, og intervjuene er tatt opp digitalt og transkribert anonymisert.

I analysen av data har jeg sett på NAV-kontoret og flyktningetjenesten i Fjord kommune som en case. Casestudier søker etter dybdebeskrivelser av en enhet og inneholder rike beskrivelser av casens kontekst (Creswell, 1998, s. 61-63). Jeg ønsket å få dype beskrivelser av tjenestenes oppbygging og organisering fra medarbeiderne samt deres syn på samarbeid omkring introduksjonsprogrammet og hurtigsporet. I tolkningen av data anerkjenner jeg at jeg har et 
annet faglig ståsted enn informanten. Dette kan resultere i at mitt perspektiv er et annet enn det informanten har (Thagaard, 2018). Samtidig er konstruksjonen av data påvirket av samspillet jeg som forsker har med personene i feltet. De kvalitative dataene jeg har, er dermed et resultat av hvordan jeg forstår informantenes beskrivelser av samarbeid og deres syn på egen arbeidssituasjon.

Siden datamaterialet er hentet fra én kommune i én landsdel, og organisering av flyktningarbeid vil variere fra kommune til kommune, er funnene og diskusjonene ikke direkte generaliserbare. Men siden samarbeid foregår i alle flyktningetjenester og NAV-kontor omkring i landet og er en prioritert målsetting hos myndighetene (Riksrevisjonen, 2019), kan funn og drøftinger i dette kapittelet være av interesse for alle parter i samarbeidsrelasjonen.

\section{INTRODUKSJONSPROGRAM OG HURTIGSPOR}

Som gjennomgått innledningsvis er formålet med introduksjonsprogrammet og hurtigsporet å få nyankomne flyktninger i jobb. For å kunne få til dette kreves det et samarbeid mellom kommune og stat. Gjennom lokale samarbeidserklæringer og rundskriv blir involverte instanser forpliktet til å samarbeide, og det blir tydeliggjort hvordan dette samarbeidet skal foregå (Kunnskapsdepartementet, 2017, punkt 2 og 4).

\section{Introduksjonsprogram}

I 2020 ble integreringsloven vedtatt med det formål at «innvandrere får gode norskkunnskaper, kunnskap om norsk samfunnsliv, formelle kvalifikasjoner og en varig tilknytning til arbeidslivet (integreringsloven, 2020, $\$ 1$ ). Tidligere ble integreringsloven kalt for introduksjonsloven, og i 2003 var introduksjonsordningen en frivillig ordning for kommunene. I 2004 ble kommunene pålagt å tilby et introduksjonsprogram i henhold til introduksjonsloven (Djuve \& Kavli, 2015). I 2020 ble det bestemt at personer som faller inn under integreringsloven (2020) $\$ 9$ a-g har rett og plikt til å delta i introduksjonsprogrammet. Det ble også bestemt i 2020 at kommunene skal tilby introduksjonsprogram basert på de nyankomne flyktningers formelle utdanning og sluttmål. Det vil derfor variere fra person til person hvor lang tid de er i introduksjonsprogrammet. For eksempel sluttmålet for nyankomne flyktninger som minimum har utdanning på videregående nivå fra før, skal være i introduksjonsprogrammet mellom tre til seks måneder med mulig forlengelse med inntil seks måneder (integreringsloven, 2020, \$13). 
Viktigheten av et velfungerende samarbeid mellom kommuner og NAV lokalt fremheves i Rundskriv G-27/2017 (Kunnskapsdepartementet, 2017). Rundskrivet beskriver forpliktelser og ansvar mellom kommune og Arbeids- og velferdsetaten i introduksjonsprogrammet og kan anvendes som en samarbeidsavtale mellom involverte instanser i introduksjonsprogrammet. Rundskrivets formål er å gi tydelige retningslinjer for samarbeidet mellom involverte instanser i introduksjonsprogrammet. Det presiseres at det er betydningsfullt at man får til et velfungerende samarbeid for å unngå dobbeltarbeid, men også for å sikre tydelig ansvarsfordeling og bidra til et målrettet og effektivt introduksjonsprogram. Kommunene skal samarbeide med Arbeids- og velferdsetaten (NAV stat) dersom en deltaker trenger videre oppfølging av NAV etter sluttført programperiode. NAV skal delta i et samarbeid om deltakere i et tidlig stadium av introduksjonsprogrammet, samt delta i samarbeidsmøter om den enkelte deltaker når det er behov for det (Kunnskapsdepartementet, 2017, avsn. 3). NAV skal også bistå i kartleggingen av den enkeltes behov og arbeidsevne, dette for å kunne vurdere egnede arbeidsmarkedstiltak som for eksempel kan anvendes i et potensielt hurtigsporløp (Arbeids- og sosialdepartementet, 2016).

\section{Hurtigsporet}

Hurtigsporet består av tiltak som allerede eksisterer i NAV, som for eksempel lønnstilskudd og mentorstøtte på arbeidsplassen (Arbeids- og sosialdepartementet mfl., 2016; Rambøll \& Halogen, 2019). Tiltaket foregår innenfor introduksjonsprogrammets rammer, hvilket fordrer et tett samarbeid mellom den kommunale flyktningetjenesten og NAV. NAV skal kunne gi arbeidsrettet bistand og informasjon om arbeidslivet (NAV-loven, 2006). Ved bruk av hurtigsporet ønsker man å utnytte synergieffekter av at kvalifisering og språkopplæring kan skje samtidig med arbeid. Et premiss for at deltakerne i et hurtigspor skal ha utbytte av tiltaket, er at flyktningetjenesten og NAV kartlegger flyktningenes kompetanse samt tilbyr utdannings- og yrkesveiledning som passer den enkelte. De skal også velge ut aktuelle kandidater til hurtigsporet, utarbeide en individuell plan (heretter integreringsplan, jfr. integreringsloven, 2020) for oppfølging av den enkelte, vurdere hvor mye oppfølging kandidaten trenger, samt vurdere muligheter for jobb (Arbeidsog sosialdepartementet, 2016; Riksrevisjonen, 2019). Integrerings- og mangfoldsdirektoratet (IMDi) (2019) har laget en liste med flere punkter som beskriver hvordan et samarbeid og organisering av hurtigspor bør være. IMDi 
(2019, punkt om organisering og samarbeid) skriver blant annet at det er viktig med tidlig involvering av medarbeidere i NAV som har arbeidsmarkedskompetanse, slik at de kan delta i arbeidet med kartlegging og integreringsplan. I tillegg er det også viktig at det utarbeides rutiner som beskriver hvem som har ansvar for hva, i arbeidet med hurtigsporet.

Det finnes lite kunnskap om hurtigsporet og hvordan dette skal organiseres (Rambøll \& Halogen, 2019; Berg \& Kullerud, 2017; Pettersen, 2018). Det vi vet, er at det er knyttet usikkerhet omkring hurtigsporets innhold, hvordan man skal rekruttere potensielle hurtigsporkandidater, og ansvarsfordelingen mellom involverte instanser.

\section{ANSATTES PERSPEKTIVER PÅ ORGANISERING OG SAMARBEID}

Etter at jeg hadde kodet, kategorisert og meningsfortolket datamaterialet, var det særlig tre temaer som gikk igjen i alle intervjuer: 1) organisering av tjeneste(r), 2) samarbeid omkring flyktninger i introduksjonsprogrammet og 3) organisering og samarbeid omkring hurtigsporet. Jeg vil nå gå nærmere inn på disse.

\section{Organisering av flyktningetjenesten og det lokale NAV-kontoret - generalister eller spesialister?}

I Fjord kommune er introduksjonsprogrammet og kvalifiseringsarbeidet med flyktninger lagt til en relativt nyopprettet enhet utenfor NAV. Der er flyktningetjenesten en del av en større sektor med flere andre enheter, deriblant NAV kommune. Det betyr at flyktningetjenesten og NAV kommune har en felles overordnet leder, men er organisatorisk atskilte enheter.

Flyktningetjenesten var tidligere en del av NAV. Kommunalsjefen i Fjord kommune fortalte hvorfor instansene ikke lenger er underlagt samme enhet:

Vi valgte å ta ut flyktningetjenesten [...] fra NAV-kontoret, og det var med bakgrunn $\mathrm{i}$ at vi hadde ingen god erfaring de årene vi hadde flyktningetjenesten inne i NAV. Vi mista litt kontrollen, rett og slett. Vi opplevde på flyktningarbeidet at alle saksbehandlerne våre som tidligere arbeidet $\mathrm{i}$ flyktningetjenesten, ble litt $[\ldots]$ 
Spist opp av andre oppgaver i NAV-kontoret, statlige oppgaver. Vi fikk ikke brukt våre ressurser godt nok på dette her med å ta flyktningene godt imot når de kommer, [...] og sikre at de får en god overgang når de kommer til Norge, altså det å være tett på. Man må jobbe tett på dem, men det fikk man ikke tid til mer, så derfor valgte vi å gå ut.

Sitatet viser flere ulike vurderinger om hvorfor Fjord kommune har organisert introduksjonsprogrammet og kvalifiseringsarbeidet utenfor NAV. Kommunalsjefen forteller at de mistet kontrollen, at de måtte håndtere statlige oppgaver og dermed ikke fikk brukt de ressursene de hadde, godt nok. Studier viser at det er fordeler og ulemper både ved organisering $i$ og utenfor NAV. Ifølge Rambølls analyser (2011, s. 51-52) er det en fordel å organisere kvalifiseringsarbeidet utenfor NAV. Dette har en sammenheng med at medarbeiderne får en mer spesialisert rolle med færre ansvarsområder å forholde seg til samt en større nærhet til de nyankomne flyktningene. En annen fordel er at medarbeiderne får bedre kapasitet til å følge opp den enkelte nyankomne flyktning, noe som igjen kan påvirke både kvalitet og resultatoppnåelse i kommunens introduksjonsprogram. Samtidig viser analysene at medarbeiderne i små program som er organisert $i \mathrm{NAV}$, har flere oppgaver knyttet til den enkelte flyktning i introduksjonsprogrammet, men at de også får flere oppgaver som ikke er direkte knyttet til programmet. Fordelen med å organisere flyktningarbeidet $i \mathrm{NAV}$ er at medarbeiderne har kompetanse på for eksempel arbeidsevnevurderinger som er relevante i tilfeller der nyankomne flyktninger ønsker å gå ut i ordinært arbeid. Dette er kompetanse som man nødvendigvis ikke har, der kvalifiseringsarbeidet er lagt utenfor NAV (Rambøll, 2011, s. 51-52). Andre argumenter er at de nyankomne flyktningene vil ha nærhet til sosial- og trygdesystemet (Tronstad, 2015, s. 47). Samtidig er det viktig å bemerke at sosiale tjenester ikke bare omfatter økonomisk bistand, men også sosialfaglig bistand. Dette innebærer blant annet råd og veiledning, som kan bidra til å forebygge og løse ulike sosiale problemer, eller som kan hemme enkeltpersoners overgang til arbeid (Sosialtjenesteloven, 2009, $\$ \$ 1$ og 17). Felles for disse ulike studiene er at alle konkluderer med at det ikke finnes én organiseringsmodell som er universell og fungerer for alle kommuner og NAV-kontorer (Rambøll, 2011; Tronstad, 2015; Djuve, Kavli, Sterri \& Bråten, 2017). Ifølge kommunalsjefen har Fjord kommune prøvd å finne en løsning som kan gagne både 
flyktningetjenesten og NAV. Dette har de gjort ved å ta flyktningetjenesten ut av det lokale NAV-kontoret og plassert den i en egen enhet.

I Fjord kommune har NAV en kommunal leder og en statlig nestleder. NAV-loven $(2006, \$ 14)$ sier at hvert enkelt NAV-kontor skal ha en avtale mellom Arbeids- og velferdsetaten (NAV stat) og kommunen, der avtalen skal inneholde bestemmelser om blant annet organisering og utføring av oppgaver på hverandres myndighetsområder. Dette betyr at en kommunal leder i NAV-kontoret vil ha samme mandat som en statlig leder til å utøve myndighet på samme områder; oppsigelse, avskjed, ansettelse og lignende (NAV-loven, 2006). Dette betyr at i Fjord kommune har den kommunale lederen for det lokale NAV-kontoret hovedansvaret for både den statlige og den kommunale styringslinjen i kontoret, og derfor myndighet innenfor begge styringslinjene.

NAV-kontoret i Fjord kommune er organisert slik at alle ansatte arbeider både med kommunale og statlige oppgaver, uavhengig om de er statlig eller kommunalt ansatt. I intervju med flere av medarbeiderne i NAV kom det frem at de har en portefølje med personer som de blir tildelt etter fødselsdato. Dette innebærer at hver veileder i sin portefølje har personer i alle aldre og med ulike hjelpebehov og ulik landbakgrunn. Det vil derfor variere blant medarbeiderne i NAV hvor mange nyankomne flyktninger i introduksjonsprogram de har i sin portefølje. Hovedtanken er at brukerne i det lokale NAV-kontoret skal møte én medarbeider, fremfor å forholde seg til flere ulike medarbeidere.

Det at alle jobber med ulike oppgaver, både kommunale og statlige, peker på at det lokale NAV-kontoret arbeider etter generalistperspektivet (Rambøll, 2011, s. 51). Dette innebærer at saksbehandlerne i NAV jobber helhetlig med brukerne, det vil si at saksbehandlerne kan utløse både kommunale og statlige virkemidler. En fordel med denne måten å jobbe på er at man får dekket hele tjenesteaspektet og kan tilby en helhetlig og koordinert tjeneste til brukerne, som også var formålet med NAV-reformen (Andreassen \& Reichborn-Kjennerud, 2009, s. 64-65). En ulempe med generalistrollen er at man får mer omfattende arbeidsoppgaver på tvers av ulike områder. En av medarbeiderne i NAV sa:

[...] [Og] det er jo fordi at det er fastsatt hvordan oppfølging du skal ha, en som har AP skal [for eksempel] ha oppfølging minimum hver tredje måned. Realiteten er jo at man må ha mye mer enn 
det! [...] Altså alt det vi gjør, er målstyrt. Så hvis du ikke har hatt oppfølging på en person på seks måneder, så lyser.. plinger det nesten et rødt lys. Du føler jo som ansatt at hvis ditt navn kommer på en foil [og] det sitter tjue stykker og ser på ... hvor det står at du er veileder [og det står på foilen at] personen har ikke snakket med noen på et år, så synes man jo det er litt dumt.

Medarbeideren peker i sitatet ovenfor på hvordan store og varierte arbeidsoppgaver på sikt kan føre til større belastninger og mindre opplevelser av mestring, da det kan tenkes at omfanget av arbeidsoppgavene blir for store for den enkelte medarbeider. Den samme medarbeideren forteller videre at det er folk som arbeider mye overtid for å ta unna arbeidet, og at dette dermed går ut over oppfølgingssamtalene som de ikke rekker å ta. Medarbeideren forteller at årsaken er uklar:

Jeg vet ikke om det er for stor portefølje, men vi har i hvert fall for mange arbeidsoppgaver i den porteføljen vi har. Og at konsekvensene dermed blir at du hopper tjue ganger på forskjellige ting. [...] Man føler at man ikke blir hundre prosent kanongod på det man burde.

Vi ser at medarbeiderne i NAV har mange omfattende og ulike arbeidsoppgaver, og som sitatene viser, kan dette gå utover mestringsfølelsen og motivasjonen hos den enkelte. Opplevelsen av å være middels god på flere områder, men ikke spesialist på enkelte områder, kan dermed påvirke arbeidsprestasjonen.

En av medarbeiderne i flyktningetjenesten som tidligere jobbet i NAV, uttrykte også sine tanker omkring generalistrollen og sa: «[...] det fungerer ikke i praksis. [...] For dette kontoret så tror jeg at man må satse mer på spesialister, eventuelt team, hvor man prøver å dekke bestemte oppgaver.»

Som tidligere nevnt innebærer generalistrollen, ifølge Andreassen og Reichborn-Kjennerud (2009, s. 64-65), at saksbehandlerne dekker hele tjenestespekteret i NAV-kontoret. Med utgangspunkt i sitatene ovenfor ser det ut til at begge parter ønsker seg en spesialisering innad i NAV. Dersom NAV-kontoret hadde satset på en spesialistordning fremfor generalistrollen, kan det tenkes at flere i NAV får spisskompetanse på enkeltområder som for eksempel flyktninger og arbeid. Dette kan føre til at saksbehandlere i NAV ser de samme utfordringene som flyktningetjenesten gjør, og at det kan bli en 
tydeligere ansvarsfordeling og problemforståelse omkring introduksjonsprogrammet. En spesialisering i NAV-kontoret kan også tenkes å gi nyankomne flyktninger bedre individuell bistand, sammenlignet med generalistrollen. Fossestøl, Breit og Borg (2014, s. 30) sier derimot at det ikke finnes en entydig konklusjon om hvorvidt generalist/spesialist fungerer i NAV-kontorer. De skriver «... Vi [vet] for lite om både innhold i og hva som kjennetegner betingelsene for å lykkes med grad og omfang av spesialisering» (Fossestøl, Breit \& Borg, 2014, s. 33). Informantene i denne studien ser derimot ut til å være tydelig i sin sak: De ønsker seg en spesialisering.

\section{Samarbeid om introduksjonsprogrammet - nettverk og relasjoner er avgjørende}

Tett samarbeid mellom de lokale NAV-kontorene og kommunenes introduksjonsprogram har vært en sentral føring over flere år. Riksrevisjonens rapport viser at samarbeid mellom instansene kan være utfordrende fordi arbeidsoppgavene er krevende. Et velfungerende samarbeid krever at samarbeidsavtalene mellom kommune og NAV blir overholdt, og at kommuneledelsen har god styring (Riksrevisjonen, 2019, s. 116).

I henhold til integreringsloven $(2020, \$ 12)$ skal kommuner så snart som mulig og innen tre måneder etter bosetting av nyankomne flyktninger legge til rette for introduksjonsprogram. For å få rett og plikt til å delta i introduksjonsprogrammet må den nyankomne flyktningen oppfylle kravene i henhold til integreringsloven $(2020, \$ 9 \mathrm{a}-\mathrm{g})$. Ut fra intervjuene med programrådgiverne i flyktningetjenesten kom det frem at kommunen konsekvent venter med å starte med introduksjonsprogram for nyankomne flyktninger til det har gått tre måneder etter ankomst. For nyankomne flyktninger som for eksempel er alene, har høyere utdanning eller som er motiverte for å komme i gang med språkopplæring, eller som ønsker å komme raskt ut i arbeid, kan det å vente tre måneder før programstart antas å være demotiverende. Ifølge Rambøll og Halogen (2019) vil et hurtigspor være relevant for personer som er motiverte for å komme raskt i arbeid (Rambøll \& Halogen, 2019), og det at flere da må vente i tre måneder, kan påvirke denne prosessen negativt.

Programrådgiverne i kommunen skal utarbeide en integreringsplan sammen med den nyankomne flyktningen, og det skal gjøres rede for hvilke arbeids- eller utdanningsrettede tiltak den nyankomne flyktningen kan dra nytte av (integreringsloven, 2020, $\$ 15$ ). Lederen i flyktningetjenesten 
fortalte at hvis en nyankommet flyktning ønsker å ta et utdanningsløp, skal programrådgiverne samarbeide med kontaktlærer i voksenopplæringen for videre oppfølging. Dersom den nyankomne flyktningen ønsker å gå i et arbeidsløp, blir det tilbydd et parallelt løp, som betyr at den nyankomne flyktningen er ute på en arbeidsplass to dager i uken, mens de resterende tre dagene er vedkommende deltaker i introduksjonsprogrammet.

Videre fortalte lederen i flyktningetjenesten at nyankomne flyktninger som ønsker å arbeide, blir satt i kontakt med en medarbeider i NAV. Lederen sa at medarbeiderne i flyktningetjenesten skal ta kontakt med NAV minst tre måneder før programslutt. Dette gjøres ved at de sender en liste over personer som ønsker å jobbe etter endt introduksjonsprogram. I dette brevet blir det også tydeliggjort at flyktningetjenesten ønsker å ha et trekantmøte mellom medarbeideren i NAV som har den nyankomne flyktningen i sin portefølje, den nyankomne flyktningen selv og medarbeideren i flyktningetjenesten. Disse skal diskutere videre progresjon for vedkommende sammen. Formålet er at nyankomne flyktninger i introduksjonsprogrammet skal få en smidig overgang fra introduksjonsprogrammet til NAV.

Medarbeiderne i flyktningetjenesten sa at de er frustrerte når det kommer til samarbeidet med NAV. De fortalte at de sender listen med programdeltakere som har arbeid som mål, til NAV tre måneder før programslutt, men ikke får respons fra medarbeiderne i NAV. Lederen i flyktningetjenesten fortalte:

[...] [NAV] klarte ikke å møte oss på samarbeid rundt deltakerne. På møter fikk vi beskjed om at NAV skal følge opp [flyktningene], men vi fikk aldri tak i en saksbehandler på NAV som ville møte våre saksbehandlere. [...] jeg sendte fire purringer til NAV, [men] fikk ikke kontakt. [De 13 flyktningene det gjaldt] endte rett og slett opp med å stille seg [i kø] hos NAV og søkte om sosialhjelp.

Lederen i flyktningetjenesten opplever det som svært frustrerende og trist at nyankomne flyktninger ender opp med å søke sosialhjelp fremfor statlige arbeidsrettede tiltak i regi av NAV fordi det er vanskelig å få til møter med NAV. En av medarbeiderne i NAV bekreftet at samarbeidet kan være utfordrende «Jeg skulle ønske vi hadde bedre samarbeid med flyktningetjenesten. Altså, fra mitt ståsted, så ser jeg at vi ikke har mye samarbeid. [...] jeg skulle ønske vi hadde samarbeid. [...] Vi har ikke et effektivt samarbeid, det har vi ikke.» 
Da vi spurte medarbeideren i NAV hvorfor de erfarer disse utfordringene i samarbeidet med flyktningetjenesten, forklarte vedkommende:

Nei, vi har internt organiseringsproblemer, vi har bemanningsproblemer, vi har ... litt problemer mellom stat og kommune, internt. Ikke sånn stat og kommune, men akkurat på grunn av bemanningen kanskje, så har vi litt.. Folk mener de har for mye å gjøre, så de kommunale oppgavene blir nedprioritert. La oss si det sånn. Hovedsakelig telles de statlige oppgavene.

Dette viser at oppgavefordelingen kan skape utfordringer også for hvorvidt nyankomne flyktninger kommer i arbeidsrettede tiltak i regi av NAV, eller om de søker sosialhjelp. Vi kan dermed ikke utelukke at fordelingen av arbeidsoppgaver kan påvirke introduksjonsprogrammets måloppnåelse.

Videre ser vi at noen av medarbeiderne i flyktningetjenesten ikke erfarer de samme samarbeidsproblemene. Medarbeidere som tidligere har jobbet $\mathrm{i}$ NAV, sier at de ikke har særlige problemer med å få kontakt med medarbeiderne i NAV. En av medarbeiderne i flyktningetjenesten som tidligere jobbet i NAV, beskrev det slik:

[...] i det samarbeidet som jeg har med NAV, med mine oppgaver og mitt arbeidsfelt, så opplever jeg at jeg får svar når jeg vil ha det. Jeg føler at jeg har en.. en god connection dit ned på en måte [latter]. At jeg føler også at jeg har litt posisjon der nede, hvis dere skjønner hva jeg mener, i og med at jeg har hatt den stillingen jeg hadde $[. .$.$] . De svarer meg kanskje fortere enn de svarer andre$ veilederne.. Så av og til er det slik at når det har vært en sånn hvor veileder her [i flyktningetjenesten] har prøvd tre, fire ganger, så sender de det videre til meg, og så får jeg et svar med én gang.

Dette kan bety at i relasjonen mellom NAV og flyktningetjenesten i denne kommunen er nettverk og relasjoner avgjørende faktorer for hvorvidt man får kontakt med medarbeiderne i NAV eller ikke. At medarbeiderne i NAV ikke svarer på henvendelsene til de i flyktningetjenesten om et trekantmøte, er motsatt av Riksrevisjonens (2019) funn, der det fremheves at flesteparten av undersøkte NAV-kontorer omkring i landet blir aktive i avslutningen av introduksjonsprogrammet. Med utgangspunkt i disse funnene ser det ut til 
at denne typen samarbeidsutfordring som eksisterer mellom NAV og flyktningetjenesten, er særskilt for Fjord kommune.

Utsagnene vi har sett, som påpeker liten bemanning i forhold til mengden arbeidsoppgaver som skal gjøres, er gjentakende i flere av intervjuene med medarbeiderne i NAV. I intervjuene kom det frem at de statlige oppgavene er omfattende, og at det tar tid å få gjort dem. Samtlige av medarbeiderne fremhevet at det sterke fokuset på statlige oppgaver har gjort at de er blitt veldig gode og får gode resultater på akkurat dette. At det lokale NAVkontoret har gode resultater når det kommer til de statlige oppgavene, er et paradoks, da det er statlige arbeidsmarkedstiltak som for eksempel lønnstilskudd som skal anvendes når flyktninger skal i jobb. At den statlige styringen har forrang i NAV, finner også Bay, Breit, Fossestøl, Grødem og Terum (2015) i sin rapport, der de blant annet har sett på NAVs utfordringer etter implementeringen av NAV-reformen.

Prioriteringen av de statlige oppgavene i det lokale NAV-kontoret sier lite om hvorfor flesteparten av flyktningene i Fjord kommune får økonomisk bistand fremfor å komme i jobb, da flesteparten av de statlige tiltakene er rettet mot arbeid. Prioriteringen sier også lite om hvorfor medarbeiderne og lederen i flyktningetjenesten ikke får kontakt med medarbeiderne og lederen i NAV. I henhold til integreringsloven (2020) og NAV-loven (2006) skal både NAV og flyktningetjenesten arbeide for å få nyankomne flyktninger selvhjulpne og økonomisk selvstendige. Medarbeiderne i både flyktningetjenesten og NAV sa at de ønsker et sterkere samarbeid med hverandre, men på grunn av det flere informanter kaller utydelig ansvarsfordeling av arbeidsoppgaver mellom NAV og flyktningetjenesten, er dette vanskelig å få til. En medarbeider i NAV fortalte at de i NAV ikke har fătt informasjon om hvordan ansvarsfordelingen mellom instansene er organisert, og de har heller ikke fått informasjon fra ledernivå om dette:

Vi spurte kommunen hele tiden, og da kom konfliktsituasjonen når du har roller som er uklare, og da ble det gnisninger mellom flyktningetjenesten og oss. De sender til oss, og vi sender tilbake. Vi har ikke fătt noen klare retningslinjer om hvordan vi skal samarbeide, hvem som skal gjøre hva, og derfor ble det ikke noe samarbeid heller. Vi prøvde å gjøre godt ut av det, men det skal være på plass før man går inn i et samarbeid. Vi skal få vite hva vi skal gjøre, hva flyktningetjenesten skal gjøre, og det skal være samarbeidsrutiner for å skrive hvordan skal vi få det til! 
Sitatet viser at medarbeideren mener at instansene vet hva de har ansvar for, men at det er en manglende felles forståelse for ansvarsområdene og oppgavefordelingen. Imidlertid kommer det frem i intervjuene med lederne i NAV og flyktningetjenesten at de bruker Rundskriv Q-27/2015 (Arbeidsog sosialdepartementet, 2015) som samarbeidserklæring mellom instansene. Lederen i NAV sa:

Det har vært en utfordring å få på plass samarbeidsavtalen vår, det har det vært. [...]. Men man må få tid til å gjøre det! Nå sendte jo vi utkastet til avtale, det var jo bare oppstarten, den er jo ikke ferdig [...] Vi begynner jo å komme på plass.

Mens medarbeiderne i flyktningetjenesten og NAV savner en tydelig ansvarsog oppgavefordeling for å få til et velfungerende samarbeid, fortalte lederne i de respektive instansene at det faktisk foreligger en samarbeidsavtale som sikrer nettopp dette. Sitatet ovenfor viser at denne er påbegynt, og vi ser her at den heller ikke er kjent blant medarbeiderne. Det er derfor grunn til å tro at det bør jobbes mer med å gjøre dette kjent $\mathrm{i}$ instansene. Berg og Kullerud (2017) finner at samarbeidsavtaler mellom instansene øker sjansen for at saksbehandlere i NAV er involvert i introduksjonsprogrammet, og at saksbehandlere i NAV oftere deltar i trekantmøter. Samtidig viser Riksrevisjonen (2019) at selv om kommuner og NAV-kontorer har inngått samarbeidsavtaler, er det få som har et tett og praktisk samarbeid. Dermed er jo Fjord kommune et eksempel på nettopp dette; en samarbeidsavtale er inngått, men det er likevel samarbeidsutfordringer.

I Fjord kommune tyder informantenes utsagn på at samarbeidsavtalen er underkommunisert fra ledernivå. Som følge av dette er det nærliggende å anta at medarbeiderne ikke har en tydelig visjon for hvordan samarbeidet mellom NAV og flyktningetjenesten skal fungere. Samtidig fortalte lederne at de har møter på ledernivå hver fjortende dag, men at disse ble avlyst en rekke ganger av ulike årsaker. Til tross for utfordringer i samarbeidet mellom flyktningetjenesten og NAV påpekte flere av medarbeiderne i NAV og flyktningetjenesten at de håper at hurtigsporet kan bidra til å styrke samarbeidet dem imellom. Behovet for og utfordringer med samarbeid mellom NAV og flyktningetjenesten tematiseres også i kapittel 7 i denne antologien. 


\section{Samarbeid om hurtigsporet er vanskelig fordi hurtig- sporet er lite konkretisert}

I Fjord kommune har det lokale NAV-kontoret opprettet en delstilling til en av de nyansatte medarbeiderne som spesifikt skal arbeide med hurtigsporet i tillegg til de ordinære arbeidsoppgavene i NAV. Denne medarbeideren har et mobilt kontor hos flyktningetjenesten, og deltar på møter sammen med medarbeiderne i flyktningetjenesten en dag i uka.

Samtlige av medarbeiderne i NAV og flyktningetjenesten uttrykte at de er positive til et hurtigspor, og mener dette vil være et fruktbart tiltak for å få nyankomne flyktninger med etterspurt kompetanse raskere i arbeid. Samtidig var det flere av medarbeiderne i flyktningetjenesten som undret seg over hvorfor det ikke har blitt laget tiltak som er rettet mer mot nyankomne flyktninger som ikke har utdanning eller arbeid med seg fra hjemlandet, eller personer som er analfabeter. Medarbeiderne begrunnet utsagnene sine med at personer som har utdanning fra hjemlandet, og som har kompetanse som er etterspurt i arbeidsmarkedet, ofte er mer ressurssterke enn for eksempel analfabeter, og at de mest trolig vil komme i arbeid uavhengig av et hurtigspor eller ikke. Videre sa flere av medarbeiderne i flyktningetjenesten at det ikke er så mange nyankomne flyktninger i introduksjonsprogrammet i Fjord kommune som har høyere utdanning, og at det dermed kan bli vanskelig å få flere personer rekruttert til et hurtigspor. Medarbeiderne i flyktningetjenesten mente at hovedfokuset heller bør være rettet mot ressurssvake flyktninger kontra ressurssterke flyktninger.

Medarbeiderne i NAV fortalte at hurtigsporet ikke er noe nytt, og begrunnet dette med at det fremdeles er de samme eksisterende arbeidsmarkedstiltakene (for eksempel jobbspesialisten) som skal anvendes i hurtigsporet. Dette kom særlig til uttrykk i intervjuet med lederen i NAV:

Nå har jeg sagt at $h^{*} n$ er på hurtigspor og holder akkurat på med det jobbspesialister skal [gjøre], som skal jobbe spesielt med de under tretti, men også de over tretti hvis det er noen som har det potensialet. Jeg tenker at mange av de som kommer inn under hurtigsporet, kommer også jobbspesialisten til å hjelpe.

Dette kan tolkes som at hurtigsporet allerede eksisterer i NAV i form av de allerede eksisterende arbeidsmarkedstiltakene, og at hurtigsporet dermed 
ikke er betydelig nytt annet enn at det har fătt et konkret navn, og at tiden i et ordinært løp i introduksjonsprogrammet blir redusert. På bakgrunn av dette ser det ut til at det er et større behov for tiltak og ordninger for nyankomne flyktninger som sliter med for eksempel analfabetisme, enn for ressurssterke flyktninger som har etterspurt kompetanse i arbeidsmarkedet. Dette understøttes også av forskning utført av Maximova-Mentzoni (2019) samt Maximova-Mentzoni, Spjelkavik, Frøyland, Schafft og Egeland (2019).

På spørsmål omkring hva hurtigsporet er, ga medarbeiderne i NAV og flyktningetjenesten et generelt bilde av hurtigsporet og viste til samarbeidserklæringen «om raskere integrering av innvandrere med fluktbakgrunn i arbeidslivet» (Arbeids- og sosialdepartementet mfl., 2016). I intervju med medarbeideren i NAV som er ansatt til å arbeide med hurtigsporet, spurte vi hvordan vedkommende har tolket hurtigsporet. Vedkommende mener at det er snakk om arbeidsrettet oppfølging, og at det er det eneste som er tydelig med ordningen:

[...] det skal være rettet mot arbeid, og at man skal arbeide med grupper som er nesten på vei ut av introduksjonsprogrammet for egen maskin, som trenger at NAV er med på å veilede i forhold til arbeidsmarked, kompetanse, kartlegging av kompetanse og så videre.

Medarbeiderne i både flyktningetjenesten og NAV uttrykte at det var vanskelig å definere hva et hurtigspor er, og hva det skal inneholde. De begrunnet dette med at det er diffust formulert fra myndighetenes side. Dette er også noe Berg og Kullerud (2017) og Rambøll og Halogen (2019) finner i sine rapporter. En konsekvens av usikkerhet rundt hurtigsporets innhold, målgruppe, ansvarsfordeling og iverksetting av hurtigsporet har ifølge Rambøll og Halogen (2019) ført til at få personer har blitt identifisert som relevante aktører til hurtigsporet, og at hurtigsporet er implementert få steder i Norge (Rambøll \& Halogen, 2019). Dette viser at til tross for at hurtigsporet ble presentert nasjonalt i 2016, er det fremdeles lite anvendt i Fjord kommune fire år senere. For nærmere drøftinger av mulige årsaker til at hurtigsporet er lite anvendt, se kapittel 6 i denne antologien.

I intervju med lederen i flyktningetjenesten kom det frem at de i flyktningetjenesten er usikre på hva medarbeideren i NAV som skal jobbe med hurtigsporet, faktisk skal gjøre. I intervjuet med lederen i NAV spurte vi hvordan det lokale NAV-kontoret forholder seg til hurtigsporet. Lederen sa 
at NAV-kontoret forholder seg til den formelle samarbeidserklæringen fra Arbeids- og sosialdepartementet mfl. (2016), som beskriver hurtigsporet og dens organisering. Lederen fortalte videre at de har kommet sent i gang med hurtigsporet, og at de ikke har fått på plass en konkret samarbeidsavtale med flyktningetjenesten omkring hurtigsporet enda, men at de hadde begynt et lite samarbeid omkring én flyktning.

Lederen i flyktningetjenesten fortalte at i samarbeid med medarbeideren i NAV som arbeider med hurtigsporet, har de kommet frem til én flyktning som ville være relevant for hurtigsporet, og denne har utdannelse fra hjemlandet. Hvordan det gikk med flyktningen i hurtigsporet, vites ikke, men dette viser at NAV og flyktningetjenesten i Fjord kommune har begynt hurtigsporarbeidet.

Da vi spurte lederen i flyktningetjenesten om hvordan vedkommende tror samarbeidet mellom dem og NAV blir med hensyn til hurtigsporet, fortalte vedkommende at flyktningetjenesten ønsker et godt samarbeid med NAV når det gjelder å få personer raskere ut i arbeid. Det samme sa medarbeiderne i flyktningetjenesten. Flere av medarbeiderne i flyktningetjenesten sa også at de håper at hurtigsporet vil skape et bedre samarbeid med NAV, enn hva de har hatt når det gjelder introduksjonsprogrammet.

Mye tyder på at medarbeiderne og lederne i NAV og flyktningetjenesten har klare ambisjoner og er motiverte for et samarbeid omkring hurtigsporet. Hvordan samarbeidet omkring hurtigsporet har fungert i praksis, og om dette har bidratt til å styrke samarbeidet mellom flyktningetjenesten og NAV, er for tidlig å si fordi hurtigsporet var relativt nytt for Fjord kommune da datainnsamlingen fant sted.

\section{AVSLUTNING}

Jeg har i dette kapittelet vist hvordan flyktningetjenesten og NAV i Fjord kommune strever med å få til et fungerende samarbeid. Jeg har presentert data som viser at organiseringen av tjenestene, og samarbeidet om introduksjonsprogrammet og hurtigsporet, påvirker flyktningenes kvalifisering for arbeid og utdanning.

Når det gjelder organiseringen av samarbeidet mellom flyktningetjenesten og det lokale NAV-kontoret, er det fordeler og ulemper knyttet til det å organisere flyktningetjenesten utenfor det lokale NAV-kontoret. Fordelen er at flyktningetjenesten får mer nærhet til flyktningene og kan konsentrere 
seg om oppfølging, veiledning, kartlegging av kompetanse og utarbeidelse av integreringsplan. Ulempen er at avstanden mellom NAV og flyktningetjenesten er blitt større. Denne avstanden ser ut til å påvirke samarbeidet mellom instansene.

Analysen viser at hvordan NAV-kontoret løser oppfølgingen av nyankomne flyktninger, kan påvirke jobbmestringen for de ansatte. I Fjords lokale NAV-kontor er medarbeiderne generalister og skal jobbe helhetlig med brukerne. Det fører også til en mer omfattende oppgavedeling, større belastninger og mindre mestring. For medarbeiderne betyr dette også at de må vektlegge de statlige oppgavene, og at det konkrete oppfølgingsarbeidet knyttet til nyankomne flyktninger nedprioriteres. Jeg oppfatter at medarbeiderne i NAV-kontoret i Fjord kommune ønsker seg en større spesialisering innad i NAV. NAV-ansattes beskrivelser av oppgavedeling og kompetansebehov i NAVs arbeidsrettede innsats er også tema i denne antologiens kapittel 10.

Jeg fant videre at nettverk og relasjoner er essensielt i Fjord kommune hvis samarbeidet mellom NAV-kontoret og flyktningetjenesten om introduksjonsprogrammet skal lykkes. Medarbeiderne beskrev en situasjon der de som tidligere hadde vært tilsatt i NAV, lyktes med å få kontakt med det lokale NAV-kontoret, mens de som ikke hadde den samme erfaringen, ikke fikk kontakt med NAV-kontoret. Dette resulterer i manglende oppfølging av nyankomne flyktninger som nærmer seg slutten av introduksjonsprogrammet, og i ytterste konsekvens fører dette til at nyankomne flyktninger som er klare for arbeidslivet, heller ender med å søke sosialhjelp. Den tydelige inndelingen i flyktningarbeidet i ulike faser, bosetting, introduksjonsprogram og deretter arbeid eller utdanning, bidrar også til å komplisere samarbeidet. Jeg ser dermed at utydelig ansvarsfordeling mellom flyktningetjenesten og NAV-kontoret fører til dårligere samarbeid, og dermed også til at flyktninger ikke lykkes med å komme i arbeid eller utdanning.

Mye av de samme utfordringene er tydelige når jeg har sett nærmere på samarbeidet om hurtigsporet. I tillegg er hurtigsporet ikke konkretisert og heller ikke noe nytt for medarbeiderne i NAV i Fjord kommune. Dermed skal de fokusere på noe som allerede eksisterer, arbeidsmarkedstiltak, og det er uklart hvordan de skal lykkes med å løse dette hurtigere. Til tross for at Fjord kommune valgte å sette av en tidsressurs til dette arbeidet, var det svært utydelig da jeg gjennomførte intervjuene, hva denne personen skulle gjøre. Et ekstra kompliserende element er at det å sette av en tidsressurs til dette på mange måter peker på en spesialisering av en spesifikk arbeidsoppgave, noe 
som går på tvers av kommunens generalistperspektiv på arbeidsoppgavene. Jeg ser at Fjord kommune ikke setter av nok tidsressurser til hurtigsporet til at det kan tas i bruk og arbeides med blant veilederne.

Jeg kan dermed konkludere med at Fjord kommune ikke har en hensiktsmessig organisering for den arbeidsrettede oppfølgingen av nyankomne flyktninger. Dette kunne ha vært unngått dersom man for eksempel hadde team i NAV-kontoret som var spesialister på enkeltområder. Slik Fjord kommune har organisert hurtigsporet, ser jeg at det å sette inn én ekstra ressurs på mange måter dreier satsingen over mot en annen av NAVs eksisterende satsninger, nemlig jobbspesialisten i Supported Employment, en satsing som også behandles i kapitlene 1- 5 i denne antologien. Jobbspesialister har som mål å få personer ut i ordinært arbeid. De bedriver tett oppfølging, er eksperter på arbeidsmarkedet og skal sørge for at det er eller blir utviklet en god match mellom arbeidssøker og arbeidsgiver. En jobbspesialist kan være fruktbart i hurtigsporet, da deres kompetanse er spesifikt rettet mot arbeidsmarkedet og det å få folk ut i arbeid. Slik jeg ser det, kan en jobbspesialist bidra til at det blir en mer tydelig ansvars- og oppgavedeling blant medarbeiderne i NAV og kommunale flyktningetjenester.

\section{REFERANSER}

Andreassen, T. A., \& Reichborn-Kjennerud, K. (2009). Utvikling og utfordringer i lokale NAV-kontor (AFI-notat 02). Hentet fra https://hdl.handle. net/20.500.12199/6100

Arbeids- og sosialdepartementet. (2015). Samarbeid mellom kommunen og Arbeids- og velferdsetaten om introduksjonsordning for nyankomne innvandrere (Rundskriv Q-27/2015). Hentet fra https://www.regjeringen.no/no/dokumenter/samarbeid-mellom-kommunen-og-arbeids--og-velferdsetaten-omintroduksjonsordning-for-nyankomne-innvandrere/id2410809/

Arbeids- og sosialdepartementet. (2016). Enighet om et hurtigspor inn i arbeidslivet. Hentet fra https://www.regjeringen.no/no/aktuelt/enighet-om-et-hurtigspor-inn-i-arbeidslivet/id2502297/

Arbeids- og sosialdepartementet, NHO, LO, VIRKE, Unio, Spekter, Akademikerne, KS, og YS. (2016). Samarbeidserklering om raskere integrering av innvandrere med fuktbakgrunn i arbeidslivet (2016). Hentet fra https://www. 
regjeringen.no/contentassets/3950cf3809a94680b6d2d3e1920f1c06/samarbeidserklaring_integrering_arbeidslivet.pdf

Bay, A. H., Breit, E., Fossestøl, K., Grødem, A. S., \& Terum, L. I. (2015). NAV som larende organisasjon (Institutt for samfunnsforskning rapport 06). Hentet fra http://hdl.handle.net/11250/2442525

Berg, H., og Kullerud, H. (2017). Samarbeid NAV - kommune om introduksjonsprogram - en kartlegging (Proba samfunnsanalyse rapport 11). Hentet fra https://proba.no/rapport/ny-rapport-samarbeid-nav-kommune-om-introduksjonsprogrammet-en-kartlegging

Bratsberg, B., Raaum, O., \& Røed, K. (2016). Flyktninger på det norske arbeidsmarkedet. Søkelys påa arbeidslivet, 33(03), 185-207. https://doi.org/10.18261/ issn.1504-7989-2016-03-01

Creswell, J. (1998). Qualitative inquiry and research design. Choosing among five approaches. Sage publications.

Djuve, A. B. \& Kavli, H. C. (2015). Ti ärs erfaringer. En kunnskapsstatus om introduksjonsprogram og norskopplaring for innvandrere (Fafo-rapport 26). Hentet fra https://www.fafo.no/images/pub/2015/20431.pdf

Djuve, A. B., Kavli, H. C., Sterri, E. B., \& Bråten, B. (2017). Introduksjonsprogram og norskopplaring. Hva virker-for hvem (Fafo-rapport 31). Hentet fra https://www.fafo.no/images/pub/2017/20639.pdf

Fossestøl, K., Breit, E., \& Borg, E. (2014). NAV-reformen 2014. En oppfolgingsstudie av lokalkontorenes organisering etter innholdsreformen (AFI-rapport 13). Hentet fra https://hdl.handle.net/20.500.12199/6228

Integrering- og mangfoldsdirektoratet. (2021, 08. januar). Hurtigspor. Hentet fra https:/introduksjonsprogrammet.imdi.no/innhold/hurtigspor/

Integreringsloven. (2020). Lov om integrering gjennom opplæring, utdanning og arbeid (LOV-2020-11-06-127).

Introduksjonsloven. (2003). Lov om introduksjonsordning og norskopplæring for nyankomne innvandrere (LOV-2003-07-04-80).

Kunnskapsdepartementet. (2017). Samarbeid mellom kommunen og Arbeids- og velferdsetaten om introduksjonsordning for nyankomne innvandrere (Rundskriv G-27/2017). Hentet fra https://www.regjeringen.no/no/dokumenter/g-272017---samarbeid-mellom-kommunen-og-arbeids--og-velferdsetaten-om-introduksjonsordning-for-nyankomne-innvandrere/id2704662

Kvale, S \& Brinkmann, S. (2017). Det kvalitative forskningsintervju (3. utg.). Oslo: Gyldendal 
Maximova-Mentzoni, T. (2019). Kvalifiseringstiltak for innvandrere og muligheter for Supported Employment. Søkelys på arbeidslivet, 36 (01-02), 36-54. https://doi.org/10.18261/issn.1504-7989-2019-01-02-03

Maximova-Mentzoni, T., Spjelkavik, Ø., Frøyland, K., Schafft, A., \& Egeland, C. (2019). Supported Employment $i$ kvalifiseringstiltak for innvandrere: To à med metodeutprøving og metodeutvikling $i$ àtte forsøksprosjekter (AFI-rapport 02). Hentet fra https://hdl.handle.net/10642/8916

NAV-loven. (2006). Lov om arbeids- og velferdsforvaltningen (arbeids- og velferdsforvaltningsloven) (LOV-2006-06-16-20).

Olsen, B. (2019). Flyktninger i og utenfor arbeidsmarkedet 2017 (Statistisk Sentralbyrå).

Pettersen, I. (2018). Organisering av samarbeid mellom kommune og NAV om raskere integrering av flyktninger - «Hurtigsporet». (Masteravhandling). UiT Norges arktiske universitet, Tromsø. Hentet fra https://hdl.handle.net/10037/13150

Rambøll. (2011). Analyse av resultatoppnåelse i introduksjonsordningen (Rambøll Management Consulting). Hentet fra https://no.ramboll.com/-/media/images/rm/rm-no/pdf/publikasjoner/2011/21011375_fou_introduksjonsordninger.pdf

Rambøll \& Halogen. (2019). Hurtigspor for nyankomne flyktninger (Rambøll Management Consulting \& Halogen). Hentet fra https://www.imdi.no/contentassets/44537335b14c4381b93f00d598269429/hurtigspor.pdf

Riksrevisjonen. (2019). Riksrevisjonens undersøkelse av myndighetenes arbeid med å integrere innvandrere gjennom kvalifisering og arbeid. Dokument 3:4 (20192020). Hentet fra https://www.riksrevisjonen.no/rapporter-mappe/no-20192020/undersokelse-av-integrering-gjennom-arbeid/

Sosialtjenesteloven. (2009). Lov om sosiale tjenester i arbeids- og velferdsforvaltningen (LOV-2009-12-18-131).

Thagaard, T. (2018). Systematikk og innlevelse: En innforing i kvalitative metoder. Bergen: Fagbokforlaget.

Tronstad, K. R. (2019). Flyktninger i introduksjonsprogrammet-Hvilke erfaringer har de med a delta? (NIBR-rapport 4). Hentet fra https://hdl.handle. net/20.500.12199/2873

Tronstad, K. R. (2015). Introduksjonsprogram for flyktninger i norske kommuner: hva betyr organiseringen for overgangen til arbeid og utdanning (NIBR-rapport 19). Hentet fra https://hdl.handle.net/20.500.12199/5894 